\title{
Corrective feedback, self-esteem and mathematics learning outcomes
}

\author{
Zubaidah $\mathbf{R}^{1}$, Dona Fitriawan ${ }^{1}$, Edy Yusmin ${ }^{1}$, Asep Nursangaji1, Ade \\ Mirza1 \\ ${ }^{1}$ Mathematics Education FKIP Universitas Tanjungpura, Indonesia \\ $₫$ zubaidah.r@fkip.untan.ac.id*
}

\section{Article Information}

Submitted April 02, 2021

Revised April 29, 2021

Accepted May 01, 2021

\section{Keywords}

Indirect Corrective Feedback; Mathematics Learning Outcomes; Prior Mathematics Knowledge; Self-Esteem.

\begin{abstract}
One of the strategies to respond the formative assessment results is corrective feedback. Through corrective feedback, it can be verified and elaborated the part of each items where an error occurs which must be reviewed and corrected by students based on the signs given. The purpose of this research is to review the effect of corrective feedback on formative evaluation and mathematics self-esteem on student's mathematics learning outcome on junior high school by controlling the prior mathematics knowledge of students. The samples were 120 seventh grade students in junior high school on first semester chosen by using random sampling. The method in this research is quasi experiment by using the design of treatment by level $2 \times 2$. Data were analyzed by using analysis of covariance (ANCOVA). After controlling the prior mathematics knowledge of students, in general, direct corrective feedback was more suited to increase mathematics learning outcomes on junior high school student than indirect corrective feedback. There was an interaction effect on providing corrective feedback and self-esteem on the mathematics learning outcomes. For the student who have high selfesteem, indirect corrective feedback is more suitable to increase mathematics learning outcomes while for the students who have low selfesteem, direct corrective feedback is more suitable to increase mathematics learning outcomes. It is recommended to the mathematics teachers to provide corrective feedback after provision of formative assessment in their class.
\end{abstract}

\section{INTRODUCTION}

Mathematics Knowledge is an important subject for developing logical, critical and rational thinking skills. Mathematics is needed as the other knowledge mastery and it also applied in various problem solving, whether it is related to daily life or the the other knowledge. Mathematics also has a role in preparing the students to face the transformation and challenge in social life. However, the students' achievement for mathematics in real life is still far from expectations quoted (Saputro et al., 2015).

The low quality of mathematics learning outcomes indicates that the learning process for mathematics has not been running optimally according to (Drost, 2005). The teacher is a determining factor for the creation of a learning atmosphere in order to develop the potential of students to become quality humans being. One of the main tasks of the teacher in carrying out part of the learning process is to assess student learning outcomes. Then (Tuzahrah et al., 2008), assessment of learning outcomes is an integral part of the learning process. Conducting continuous formative assessments, increasing the intensity of the feedback provided, and following up on the results of the formative assessment are ways to overcome weaknesses in the learning process. The more intense the formative tests are given the more motivated 
students will be to improve understanding and mastery of teaching material so that mathematics learning outcomes will increase more than before.

Providing a continuous response to the evaluation results will stimulate students to study harder, try to correct deficiencies, and build their understanding in the right way. As students study, they will often need help figuring out the answer to why their assignment went wrong according to (Woolfolk, 2008). A fact shows that the correction pattern towards learning assignment and students' test result which is implemented by the teacher all this time is less communicative and innovative. The results of summative or sub-summative assessments are often not returned to students and are not given feedback, if returned students only get the initials and correct answers and red strokes on wrong answers, usually the teacher more often announces the acquisition score for the student who gets the highest score and the lowest score. Feedback on assignment implementation and other assessments are still conventional, only discussing certain questions classically, for example, questions that are considered difficult for most students, and the approach that is often taken is to ask one of the students to write down the answer on the board.

This condition shows that the assessment result obtained by the students is not getting any corrective response from the teacher, resulting in students being demotivating to understand and to fix their worksheet mistakes. The not yet intensive implementation of formative assessments accompanied by the provision of responses and follow-up to the results of assessments by mathematics teachers will have the potential for the accumulation of student misunderstandings regarding mathematics material. If it is left behind, this can have an impact on the accumulation of student learning difficulties and the bigger obstacle for them to gain a better learning outcomes, according to (Zubaidah \& Bistari, 2019).

Corrective feedback is one of the strategies which can be used to react onto formative assessment result. By using corrective feedback, the students realize the existing mistakes and also deepen their understanding of the knowledge gained through learning experience so that learning difficulties can be overcome and in the end the quality of learning outcomes becomes much better. Providing corrective feedback is seen as an integrated activity in learning that aims to help students correct learning mistakes. Corrective feedback is a teacher's response towards students learning mistakes, according to (Brockley, 2008). Based on this definition, the provision of corrective feedback is seen as an important pedagogical activity to be carried out in an effort to improve student competence, especially in mathematics. The importance of providing feedback in the form of information on assignments and their improvements is empirically shown by the results of research by (Hattie \& Timperley, 2007) where the giving of feedback by the teacher has a strong influence on student achievement with an effect size of 0.76 .

Refers to those opinions, it can be concluded that corrective feedback is a response given by the teacher towards students' work mistakes on their learning assignment. Providing corrective feedback is considered as an integrated activity in learning which aims to assist students in correcting learning mistakes. Corrective feedback techniques can be implemented orally and in writing from research by (Ellis, 2008). Oral corrective feedback is separated into two strategies, those are explicit corrective feedback and implicit corrective feedback. Then (Ellis, 2010), stated, a written corrective feedback consists of: (1) direct corrective feedback (DCF), which means the teacher gives response toward the mistakes on answers and also provides the correct one for the students, and (2) indirect corrective feedback (IDCF), the 
teacher gives a clue that there is a mistake but not giving any correct answer. In this research, providing corrective feedback is separated by direct corrective feedback (DCF) and indirect corrective feedback (IDCF).

The accuracy and effectiveness of providing corrective feedback depends on students' characteristics, one of the characteristics is student's self-esteem towards mathematics. Selfesteem is one of internal factors which is strongly suspected in affecting the successfulness of mathematics learning. The results of the research by (Pyle \& Poston, 2006), concluded that there was an effect of self-esteem on learning achievement in Mathematics and Language. Then (Branden, 1992) stated that self-esteem is an appreciation for the eligibility / preciousness / value and self-interest and has a character that is responsible for themselves and to act responsibly to other people. And the other opinion about self-esteem is individual appraisal on satisfaction and acceptance on eligibility, significance, successfulness, attractiveness, competency or ability which is expressed in individual belonging attitudes towards themselves, according to (Baldwin \& Hoffmann, 2012; Lutan, 2003).

Based on that definition, we can conclude that self-esteem shows how far an individual appraises and trusts the quality of themself which is revealed from their attitudes toward it. Students learning outcomes also can be strongly affected by the learning readiness or intellectual maturity and the previous learning experiences. Learning mathematics involves hierarchical structure from high level concepts shaped on the basic concept of prerequisite which is needed to be mastered. Winkel cited by (Rahmi et al., 2015), stated that earlier knowledge is as a prerequisite knowledge needed to achieve instructional purposes. Mathematic concepts are arranged hierarchically and closely related to each other that it shapes more complex concept. This means that the previous mathematic knowledge known by the students becomes the basic understanding to learn the next material. In behalf of hierarchical nature of mathematics matters, learning mathematics is a continuous and sequential process that will need knowledge, excellent basic mathematic understanding on the beginning of learning for the further study based on the research by (Russeffendi, 2012). Several previous researches have examined the effect of providing corrective feedback on learning outcomes in language contexts, according to (Elashri \& Fattah, 2013; Mirzaii \& Aliabadi, 2013b; Sayyad et al., 2013). Not much research has been found in mathematical content.

The providing corrective feedback that is appropriate with student characteristics will be the strengthening resources and encouragement to optimally comprehend the teaching materials in fixing the mistakes made on assignment completion or formative evaluation. Leeman of cited by (Leeman, 2013), states that providing corrective feedback is highly depend on the internal condition of the individual student or psychological factors. Some researchers such as Lee and Bitchener provide support for the use of direct corrective feedback, especially in the context of certain rules or structure-based knowledge. Therefore, the purpose of this research is to examine the effect of correction feedback given and mathematics self-esteem toward mathematics learning outcomes by controlling the basic knowledge of mathematics.

\section{METHODS}

This research used quasi experimental method by using the design of treatment by level $2 \times 2$. This research applied two kinds of corrective feedback strategy which were direct 
corrective feedback (ICF) and indirect corrective feedback (ICF). Every kind of corrective feedback strategy was implemented to a group of students who have high and low selfesteem. Response variable in this research is mathematics learning outcomes. Accounted variable which also influenced on student learning outcomes is covariate variable of mathematics prior knowledge. The research design is presented in the following matrix form Tabel 1 .

Table 1. Design Experiment Treatment by Level $2 \times 2$

\begin{tabular}{lll}
\hline $\mathbf{B}$ & $\mathbf{A}$ & \\
\cline { 2 - 3 } & $\mathbf{A}_{\mathbf{1}}$ & $\mathbf{A}_{\mathbf{2}}$ \\
\hline $\mathrm{B}_{1}$ & {$[\mathrm{X}, \mathrm{Y}]_{\mathrm{ij}}$} & {$[\mathrm{X}, \mathrm{Y}]_{\mathrm{ij}}$} \\
& $\mathrm{i}=1,2, \ldots, \mathrm{k} . \mathrm{j}=1,2, \ldots \mathrm{k}$ & $\mathrm{i}=1,2, \ldots, \mathrm{k} . \mathrm{j}=1,2, \ldots . \mathrm{k}$ \\
& $\left(\mathrm{A}_{1}, \mathrm{~B}_{1}\right)$ & $\left(\mathrm{A}_{2}, \mathrm{~B}_{1}\right)$ \\
& & \\
$\mathrm{B}_{2}$ & {$[\mathrm{X}, \mathrm{Y}]_{\mathrm{ij}}$} & {$[\mathrm{X}, \mathrm{Y}]_{\mathrm{ij}}$} \\
& $\mathrm{i}=1,2, \ldots ., \mathrm{k} . \mathrm{j}=1,2, \ldots . \mathrm{k}$ & $\mathrm{i}=1,2, \ldots, \mathrm{k} . \mathrm{j}=1,2, \ldots \mathrm{k}$ \\
& $\left(\mathrm{A}_{1}, \mathrm{~B}_{2}\right)$ & $\left(\mathrm{A}_{2}, \mathrm{~B}_{2}\right)$ \\
\hline
\end{tabular}

Information:

$\mathrm{X}_{\mathrm{i}} \quad$ : Score of initial mathematical knowledge.

$\mathrm{Y}_{\mathrm{j}} \quad$ : Score of students' mathematics learning outcomes.

k : Sample size per group.

A : Corrective Feedback Formative Assessment.

$A_{1}$ : Groups of students who are subject to direct corrective feedback.

$\mathrm{A}_{2}$ : Groups of students who are subject to direct corrective feedback.

B : Self-esteem

$\mathrm{B}_{1} \quad$ : A group of students who have high self-esteem.

$\mathrm{B}_{2} \quad$ : A group of students who have low self-esteem

Population in this research is every student of seventh grade at SMP Negeri 23 Pontianak and SMP Negeri 08 Pontianak. There were 366 students who were officially registered in odd semester. The samples were 120 students chosen by using random sampling.

Based on calculation by using formula of Hoyt (Djaali \& Muljono, 2008), we obtained the reliability coefficient suitability instrument panel of learning outcome $r=0,968$. By formula KR-20 (Azwar, 2008), it was obtained that reliability coefficient test is 0,857 whereas reliability coefficient suitability instrument panel of self-esteem is 0,976 . Using the analysis of Alpha-Cronbach (Anastasi \& Urbina, 2007), could obtain instrument reliability of self-esteem 0,96863 .

This research is to examine the effect of corrective feedback on formative assessment and mathematics self-esteem on students learning outcomes by controling prior mathematics knowledge. Data were analyzed by using analysis of covariance (ANCOVA). Based on the result of ANCOVA test requirements such as normality test, homogeneity test, linearity test, significance test, and alignment tes line, it is concluded that data had met all requirements of ANCOVA test.

\section{RESULTS AND DISCUSSION}

The descriptively research result for eight cell shows on the table 2 . 
Table 2. Score Description of Students' Mathematics Learning Outcomes

\begin{tabular}{llllll}
\hline Group & N & $\begin{array}{l}\text { Min } \\
\text { Score }\end{array}$ & $\begin{array}{l}\text { Max } \\
\text { Score }\end{array}$ & Average & $\begin{array}{l}\text { Standard } \\
\text { Deviation }\end{array}$ \\
\hline$D C F$ & 60 & 11 & 40 & 26,65 & 7,14 \\
$I D C F$ & 60 & 9 & 40 & 23,78 & 8,3 \\
$S E-T$ & 60 & 11 & 40 & 27,12 & 7,24 \\
$S E-\mathrm{R}$ & 60 & 9 & 39 & 23,32 & 8,02 \\
$D C F$ \& SE-T & 30 & 11 & 40 & 25,6 & 6,98 \\
$D C F \& S E-\mathrm{R}$ & 30 & 12 & 40 & 27,7 & 5.58 \\
$I C F \& S E-\mathrm{T}$ & 30 & 13 & 40 & 28,6 & 7,29 \\
$I C F \& S E-\mathrm{R}$ & 30 & 9 & 32 & 18,9 & 6,22 \\
\hline
\end{tabular}

Based on Table 2, standard deviation score of $D C F$ group is 7,14 and standard deviation of $I D C F$ group is 8,3. This shows that the data in $D C F$ group is more homogeneous than the data from $I D C F$ group. Whereas standard deviation in $S E-T$ group is 7,24 and standard deviation in $S E-R$ group is 8,02. The data description in $S E-T$ group is more homogeneous than the data from $S E-R$ group. As well as the data for other four group of $D C F \& S E-\mathrm{T}, D C F \& S E-\mathrm{R}$, $I C F \& S E-\mathrm{T}, I C F \& S E-\mathrm{R}$, if it's reviewed from the value of standard deviation then the $D C F \&$ $S E-\mathrm{R}$ group data or the group of students which has low self-esteem and is given a direct corrective feedback is more homogeneous than the other three group data.

ANCOVA research result shows $F_{\text {count }}=6,596$ and $F_{\text {table }}=2,69$, for $\alpha=0,05$. Since

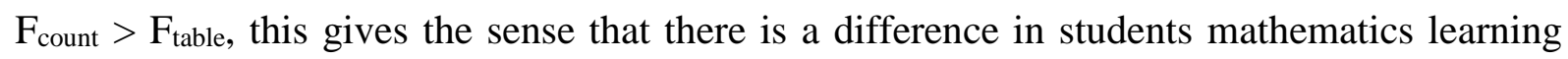
outcomes between the student who is given a direct corrective feedback and students learning outcomes who is given an indirect corrective feedback after controlling the students' basic knowledge of mathematics. Furthermore, experiment on $\mathrm{F}$ factor $\mathrm{A} \times \mathrm{B}$ by $\mathrm{F}_{\text {count }}=6,99$. and

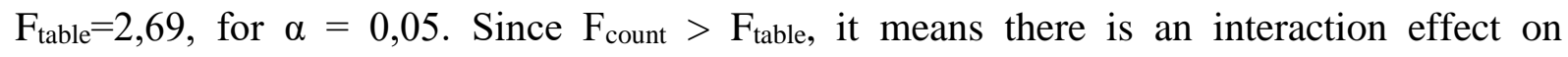
providing corrective feedback with the mathematics self-esteem towards mathematics learning outcomes after controlling the students' basic knowledge of mathematics. The analysis result shows on table 3 .

Table 3. Differences in Mathematics Learning Outcomes

\begin{tabular}{lll}
\hline Variance Resource & $\mathbf{F}_{\text {count }}$ & $\mathbf{F}_{\text {table }}$ \\
\cline { 2 - 3 } & 6,596 & $\mathbf{0 , 0 5}$ \\
\hline Corrective Feedback (DCF \& ICF) & 6,596 & 2,69 \\
Corrective Feedback and Self-esteem & 46,99 & \\
\hline
\end{tabular}

Average score is corrected for the group of students which is given a direct corrective feedback as much as 26,284, and the student who is given an indirect corrective feedback, their average scores are corrected as much as 24,146. This marks that student learning outcomes of those who are given a direct corrective feedback is higher than the student learning outcomes of those who are given an indirect corrective feedback after controlling the students' basic knowledge of mathematics.

The analysis result shows on table 4.

Table 4. The Average is Corrected by A Factor Level (Corrective Feedback)

\begin{tabular}{ll}
\hline A Factor & Corrected Average \\
\hline$D C F$ & 26,284 \\
$I D C F$ & 24,146 \\
\hline
\end{tabular}


The hypothesis testing of simple effect which is aimed to find out the appropriate form of corrective feedback with student self-esteem is analyzed by ANCOVA experiment. The difference between mathematics learning outcomes of student who is given a direct corrective feedback and learning outcomes of student who is given an indirect corrective feedback for those who have high self-esteem shows by the analysis result of $t_{\text {count }}=2,95$ dan $t_{\text {table }}=1,677$,

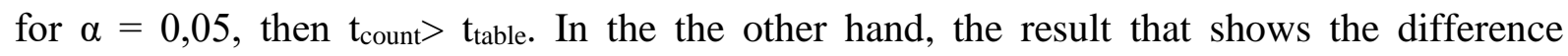
between mathematics learning outcomes of student who is given a direct corrective feedback and learning outcomes of student who is given an indirect corrective feedback for those who have low self-esteem shows by the analysis result of $t_{\text {count }}=6,60$ dan $t_{\text {table }}=1,677$, for $\alpha=$

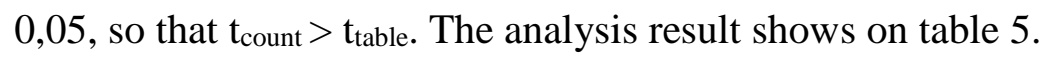

Table 5. Experiment-t Statistics Toward All A Factor Level (Corrective Feedback) for Each B Factor Level (Self-Esteem)

\begin{tabular}{lll}
\hline Factor & T count & t table \\
\cline { 3 - 3 } & & $\alpha=\mathbf{0 , 0 5}$ \\
\hline$C F^{*}$ SE High & 2,95 & 1,677 \\
\hline
\end{tabular}

Student corrected average score which is given a direct corrective feedback for those who have high self-esteem is 25,08 also student corrected average score which is given an indirect corrective feedback for those who have high self-esteem is 28,54. This means that the learning outcomes of students that is given an indirect corrective feedback is higher than learning outcomes of student that is given direct corrective feedback for those who have a high self-esteem.

Student corrected average score which is given a direct corrective feedback is 27,46 and student corrected average score which is given an indirect corrective feedback is 19,743 . It is concluded that mathematics learning outcomes of student who is given a direct corrective feedback is higher than the mathematics learning outcomes of student who is given an indirect corrective feedback for those who have low self-esteem. The analysis result shows on table 6 .

Table 6. Corrected Average on All A Factor Level (Corrective Feedback) for Each B Factor Level (Self-Esteem)

\begin{tabular}{ll}
\hline Factor & Corrected Average \\
\hline$D C F^{*}$ SE High & 25,08 \\
$I C F^{*}$ SE High & 28,54 \\
$D C F^{*}$ SE Low & 27,46 \\
$I C F^{*}$ SE Low & 19,743 \\
\hline
\end{tabular}

\section{Discussion}

The result of this research indicated that mathematics learning outcomes for students who was delivered higher direct corrective feedback was higher than the outcomes for students who was delivered indirect corrective feedback. This research was supported by the result of experimental research which was conducted by (Mirzaii \& Aliabadi, 2013a), concluding that providing direct corrective feedback is more effective than indirect corrective feedback in language lesson. Based on ANCOVA analysis, it is able to concluded that there is a very significant result. 
The result of the research conducted by (Sayyad \& Sayyadmahaleh., 2013) in writing learning skill also shows that implementation of direct corrective feedback improves student's writing skill effectively. In the other words, providing direct corrective feedback in EFL class influences on improving writing skill achievment in EFL Iran Intermediate level students. In line with the result of the research conducted by Elashri (Elashri, 2013), it concluded that providing direct corrective feedback influences on improving student's writing skill.

The other research which supports this is (Karim, 2013), in his research, it concluded that in the case of direct corrective feedback, the students who succeed to analyze an error and find out explicid information is very helpful for them in order to help them understand the mistake they did and the result of correction from teachers can be stored in their memory.

By doing corrective feedback, missunderstanding to mathemarics lessons can be reduced so the difficulty of learning can be overcome or minimized. According to psychology theory, behaviour focuses on reinforcement role in motivating the individual who learns to act in certain ways. Corrective feedback can be also considered as reinforcement which could serve to avoid the same mistakes to come up next time. Direct corrective feedback is an opinion given by teachers to the mistakes in finishing some tasks which are comments and directions to the right answer in write. Through notes and directions given by teachers to the student's incorrect work result, it can provide better description to the students as their guide when studying.

According to the theory, giving direct corrective feedback is very fit for junior high school students, they still need guide and direction from the teacher to do tasks continuously. In this context, teachers as a role model could be possibly applied in the class. By providing direct corrective feedback, it makes students focus on suggestions given by teachers in order to motivate them to achieve appreciation or better scores.

Then (Farrokhi \& Sattarpour, 2012), in their research revealed that by not disregarding the value of indirect corrective feedback, the researchers like Ferris and Roberts, who did more approach of corrective feedback, explained that teachers and students prefered direct corrective feedback, due to some reasons: first; to decrease the confusion which perhaps happens to students when they fail to understand or recall what is given to them (such as; purpose / intention from the wrong command given by teachers), second; to give information to students for assisting them to fix mistakes more completely, third; to offer feedback more clearly / explicitly on the hypothesis, and fourth; to receive feedback simultaneously (not postponed).

Remembering that mathematics is related to ideas, structures, and relations managed according to logical rules, so the message delivered to students to the revision of assigment should depend on suitability pattern logically. Explanation based on suitability pattern is given more suitably by direct corrective feedback just like what Leeman (Leeman, 2013), stated that several researchers like Lee and Bitchener supported to use direct corrective feedback especially in the context of knowledge based on structures or certain rules.

On the other hand, by giving indirect corrective feedback, it is possible for students not to be excited and not to be motivated, not to care to re-learn the correction result and to get lazy in doing some assigments till gaining the right answer. It can cause mathematics materials not to be understood by students completely, so the problems related to mathematics can not be solved well. 
The result of the hypothesis expressed that there was interaction effect between providing corrective feedback and mathematics self-esteem on mathematics learning outcomes after controling students' prior knowledge of mathematics. This showed that the effect of providing corrective feedback (direct and indirect) cannot be seperated from mathematics self-esteem (low and high) and also it showed that providing corrective feedback and self-esteem of mathematics to students can provide different influences on mathematics learning outcomes.

Providing corrective feedback depends much on students' individual internal condition related to psychological factor to respond and stimulate corection result given in improving students' understanding. Lee which was adapted by (Leeman, 2013), suggested that the combination of giving corrective feedback (direct and indirect) be effective based on student differentiation.

Students that have high self-esteem obtain the tendency in self-confidence, believe in their ability, and never give in, so they will make effort to achieve desired goal. For the students who have low self-esteem, they tend to give up and in easily, have less selfconfidence, so when they do not have external motivation, it will be more difficult to achieve better results, according to (Moran, 2013).

With the background of every student's characteristics and excellences which belong to each student's corrective feedback, it is proven that providing direct corrective feedback will give a better effect on achieving learning result if it is given to students who have low mathematics self-esteem. In the other hand, providing indirect corrective feedback will give a better effect on mathematics learning outcomes if it is given to the group of students that have high mathematics self-esteem.

Then statistics analysis result showed that students mathematics learning outcomes which is provided indirect corrective feedback higher than mathematics learning outcomes provided direct corrective feedback to the students who have high mathematics self-esteem. This research was supported by the research from (Maleki \& "E. E, 2013), which stated that there was a significant difference between direct corrective feedback group and indirect corrective feedback group. The group of indirect feedback gave a better result than the group of direct feedback did in delayed post-test to students. The fact that the indirect feedback group's result can surpass in delayed post-test perhaps implies strategic superiority in indirect feedback will have a durable effect or suitable for long term learning and students in intermediate level.

The research from (Ghandi \& Maghsoudi., 2014), which reviewed the influence of direct corrective feedback and indirect corrective feedback involving 56 random samples also acquired the same result. The research concluded that there was a diversity about the influence of implementation effectivity to two models of corrective feedback. Indirect corrective feedback is more effective than direct corrective feedback in fixing student's in spelling lesson.

Self-esteem is an internal situation on somebody which is related to psychological factor and reflect individual's ability in managing his or her potential. According to Branden, every individual has faith that he or she has prize and ability to think in order to overcome every challenge in his or her life, have responsibility character to himself and herself, to act responsibly to other people, and need appreciation for what she or he has achieved. Its implication in learning process is every assignment performed by students to show their responsibility in their learning and matched to their ability requires appreciation from teachers such as suggestion, commend, acheivement, and compliment. 
Indirect corrective feedback is a respond given by teachers as a sign and a key for answering the wrong item without giving the detail direction. Information given by the teachers to students' work sheet is relatively limited, not giving the explicit instruction to achieve the right settlement. So that is why, to finish the correction result in the form of indirect corrective feedback requires initiative, creativity and high confidence. This is matched to somebody who has high self-esteem. But if they are given direct corrective feedback, they think that they do not get any challenge, so it can raise the sense of boredom to finish their tasks.

Giving indirect corrective feedback is the same way as the general principles which is stated by (Davis, 2004), that in learning process is needed fading which is decreasing or losing some directions and guidences from teachers after students getting guided are trusted to have mastered procedure or mathematical algorithm. The student learning outcomes which has direct corrective feedback is higher than the student learning outcomes in the group which has indirect corrective feedback to students who have low mathematics self-esteem.

The advantage of direct corrective feedback is to provide students by explicit guidance about how to fix their mistakes. Ferris and Robberts taken by (Ayhan, 2011), explained that direct corrective feedback is much better than indirect corrective feedback to students which have low ability standart. Students who have low self-esteem have characteristics such as less-confidence with their idea, less-independence, less-initiative, and and having introvert characteristic. So in doing tasks, students depend on the other people's assist which is their teacher. As the statement from Lishner taken from (Hatam \& Sa, 2016), that somebody who has low self-esteem generally has less initiative, less curiousity, less confidence, to be easy to give up if having some trouble and less explorative. Seeing this condition, for them in the group who has low self-esteem sometimes dislikes the hard task, challenging, and the task that needs high analysis thoughts, so direction or clear and explicit orders is needed as a guidance in finishing unfinished tasks.

By direct corrective feedback, student's attention individually will focus more, for the order received more clearly and directional to revision will appear deeply to every students. The narrative loaded in student's answer sheet is to put their attention together clearly and well. According to (Ayhan, 2011), students are not able to fix up if they do not have idea about the correct answer and students perhaps may fix it up, yet they are not convinced that their answer is correct. Based on the hierarchical nature of mathematics, the factor of students' initial knowledge of mathematics contributes to learning outcomes and the formation of student attitudes, according to (Saragih, 2011; Somakim, 2010). The difference between this research and previous research is that the contribution made by providing corrective feedback and self-esteem to learning outcomes by controlling the prior knowledge as a covariate variable through Covarian Analysis.

\section{CONCLUSIONS}

Based on the research result, it can be concluded that generally providing corrective feedback and the level of self-esteem affect the mathematics learning outcomes for Junior High School students after controlling their basic knowledge of mathematics. A group of students that was provided a direct corrective feedback treatment gives higher learning outcomes rather than a group of students that was given an indirect corrective feedback treatment after controlling their basic knowledge of mathematics. There is an interaction effect on providing corrective 
feedback and self-esteem towards mathematic learning outcomes after controlling the students' prior knowledge of mathematics. This means that corrective feedback and selfesteem have a joint effect on mathematics learning outcomes. For students who have high self-esteem, providing indirect corrective feedback is more appropriate than providing direct corrective feedback. On the contrary, for those who have low self-esteem, providing direct corrective feedback is more appropriate than providing indirect corrective feedback after controlling the students' basic knowledge of mathematics.

Corrective feedback can be used as an alternative form of feedback in mathematics learning. Providing corrective feedback must be based on the strong will in doing a correction to an assignment and giving it some response by using a certain technique which its effectiveness already proven and it also needs the teacher's skill improvement for assisting the growth of students' potential and positive attitude accordingly and directionally in order to motivate and give positive influence on the rises of students' self-esteem so that in its turn, it can improve the students learning outcomes. It is suggested that the next research should not only look at the effect of corrective feedback on learning outcomes but need a more specific research on the development of high-level thinking, namely reflective, critical and creative thinking.

\section{AUTHOR CONTRIBUTIONS STATEMENT}

$\mathrm{RZ}$ and DF worked as the main drafter in this research. data collection and instrument design assisted by EY, AN and AM.

\section{REFERENCES}

Anastasi, A., \& Urbina, S. (2007). Tes Psikologi, terjemahan Robertus Hariono S. Imam. Jakarta: PT Indeks.

Ayhan, Ü. (2011). 1st International Conference on Foreign Language Teaching and Applied Linguistics May 5-7 2011 Sarajevo Positive Impact Of Corrective Feedback In SLA 1st International Conference on Foreign Language Teaching and Applied Linguistics. Ist International Conference on Foreign Language Teaching and Applied Linguistics, 1989, 1379-1383.

Azwar, S. (2008). Reliabilitas dan Validitas. Yogyakarta: Pustaka Pelajar.

Baldwin, S. A., \& Hoffmann, J. P. (2002). The dynamics of self-esteem: A growth-curve analysis. Journal of youth and adolescence, 31(2), 101-113.

Branden, N. (1992). The power of self-esteem: An inspiring look at our most important psychological resource.

Brockley, T. (2008). Corrective feedback and pedogogy: two activities in an online curriculum, EDU 540 Assessment 2. Http://Eslenglishclassroom.Com/1-540-2.Pdf.

Davis, et. al. (2004). Learning system design an approach to improvement of instruction. New Yok: Mic Grow-Hill. Book Company.

Djaali, \& Muljono, P. (2008). Pengukuran Dalam Bidang Pendidikan. Jakarta: PT Gramedia Widiasuara Indonesia.

Drost, J. (2005). Dari KBK sampai MBS. PT Kompas Media Nusantara (2nd ed.).

Elashri, I. I. E. A. F. (2013). The impact of the direct teacher feedback strategy on the efl 
secondary stage students' writing performance. Research Report: Mansoura University Faculty of Education Department of Curricula \& Methods English Section.

Elashri, I. I., \& Fattah, E. A. (2013). The impact of the direct teacher feedback strategy on the efl secondary stage students' writing performance." Research Report. Mansoura University Faculty of Education Department of curricula \& Methods English Section.

Ellis, R. (2008). The study of second language acquisition (2nd ed). Oxford University Press.

Ellis, R. (2010). A. framwork for investigating oral and writen corrective feedback studies in second. Language Acquisition 32, 335-349.

Farrokhi, F., \& Sattarpour, S. (2012). The effects of direct written corrective feedback on improvement of grammatical accuracy of high- proficient L2 learners. World Journal of Education, 2(2), 49-57. https://doi.org/10.5430/wje.v2n2p49

Ghandi, M., \& Maghsoudi., M. (2014). The effect of direct and indirect corrective feedback on iranian EFL learners' spelling errors. English Language Teaching, 7(8).

Hatam, S., \& Sa, T. (2016). Power distribution in EFL context: Probing the potential role of age and grade of study. ISSN Print: 1836-8743 The Iranian EFL Journal Issue 2 Iranian.efljournal@yahoo.com Chief Editors Dr. Paul Robertson. January 2014.

Hattie, J., \& Timperley, H. (2007). The power of feedback.” Review of Educational Research, 77(1). Http://Rer.Aera.Net. 88-112.

Karim, K. (2013). The effects of direct and indirect written corrective feedback (CF) on english-as-a-second-language (ESL) students' revision accuracy and writing skills. A Dissertation Submitted in Partial Fulfillment of the Requirements for the Degree of Doctor of Philosophy In the Department of Linguistics.

Leeman, P. E. (2013). Watching the signs: An examination of foreign/second language written corrective feedback. Report, Presented to the Faculty of the Graduate School of the University of Texas at Austin.

Lutan, R. (2003). Self Esteem: Landasan Kepribadian. Jakarta: Bagian Proyek Peningkatan Mutu Organisasi dan Tenaga Keolahragaan. Dirjen Olahraga Depdiknas.

Maleki, A., \& “E. E. (2013). The Effects of written corrective feedback techniques on EFL students' control over grammatical construction of their written English. Theory and Practice in Language Studies, 3(7).

Mirzaii, M., \& Aliabadi, R. B. (2013a). Direct and indirect written corrective feedback in the context of genre-based instruction on job application letter writing. Journal of Writing Research, 5(2), 191-213. https://doi.org/10.17239/jowr-2013.05.02.2

Mirzaii, M., \& Aliabadi, R. B. (2013b). Direct and indirect written corrective feedback inthe context of genre-based instruction on job application letter writing. Journal of Writing Research, 5(2), 2013, 191-213.

Moran, C. (2013). Ian fleming and the public profile of the CIA. Journal of Cold War Studies, 15(1), 119-146. https://doi.org/10.1162/JCWS_a_00310

Pyle, S. A., \& Poston. (2006). Fighting an epidemic: The role of schools in reducing childhood obesity. Journal Psychology in The Schools, Vol. 43, No. 3, 2006, 361-376. 
Rahmi, F., Puspasari, D., \& Andalas, U. (2015). Kematangan karir ditinjau dari jenis kelamin dan jenis sekolah di kota padang. 24, 24-35.

Russeffendi, E. . (2012). Dasar-Dasar Penelitian Pendidikan dan Bidang Non-Eksakta Lainnya. Bandung: Tarsito.

Saputro, M., Yadi, A., \& Dona, F. (2015). Faktor-faktor yang mempengaruhi prestasi belajar (studi korelasi pada mahasiswa pendidikan matematika IKIP PGRI Pontianak). Jurnal Pendidikan Informatika Dan Sains, 4(2), 233-246.

Saragih, S. (2011). Penerapan pendekatan pembelajaran matematika realistik dan kelompok kecil untuk meningkatkan kemampuan keruangan, berpikir logis dan sikap positif terhadap matematika siswa kelas VIII. Disertasi, PPs Universitas Pendidikan Indonesia.

Sayyad, Samadi, F., \& Sayyadmahaleh, M. M. (2013). The effect of direct corrective feedback on iranian intermediate EFL learning' writing proficiency. Asian Journal of Social Sciences \& Humanities, Vol. 2, No. 4, November 2013, 64 - 73.

Somakim. (2010). Peningkatan kemampuan berpikir kritis dan self-efficacy matematika siswa sekolah menengah pertama dengan penggunaan pendekatan matematika realistik. Disertasi, PPs Universitas Pendidikan Indonesia.

Tuzahrah, F., Zubaidah, \& Ijuddin, R. (2008). Analisis kesulitan belajar siswa dalam menyelesaikan soal bilangan berpangkat. Jurnal Pembelajaran Khatulistiwa, 1, 1-12.

Woolfolk, A. (2008). Educational Psychology; Active Learning Edition. Boston: Pearson Education, Inc.

Zubaidah, R., \& Bistari, B. (2019). Analisis kesulitan belajar anak autis pada materi penjumlahan dan pengurangan bilangan cacah SMPLB Pontianak. Jurnal Pendidikan Dan Pembelajaran Khatulistiwa, 8(11), 1-8. 